\title{
PENGARUH TEKNIK PEMBERIAN BALIKAN DAN GAYA KOGNITIF TERHADAP HASIL BELAJAR IPA
}

\author{
OLEH \\ Suleman', Hamzah B. Uno², Lukman A.R. Laliyo ${ }^{3}$ \\ ${ }^{1}$ Universitas Muhammadiyah Gorontalo \\ ${ }^{2}$ Universitas Negeri Gorontalo \\ sulema@umgo.ac.id
}

\begin{abstract}
The research aimed to understand: (1) the diffirence of learning achievement in Natural Science between students who were taught by applying direct feedback and delayed feedback, (2) the influence of interaction in giving feedback and spatial cognitive style toward learning achievement of Natural Science, (3) the difference of learning achievement of Natural Science on students who had high spatial cognitive between students who were taught by applying direct feedback and delayed feedback, (4) the difference of learning achievement on students who had low spatial cognitive students who were taught by applying direct feedback and delayed feedback.

The research was conducted at SMP Negeri 2 Bongomeme applying Factorial design by level method by having ANAVA design $2 \times 2$. The result showed that: (1) there was difference of learning achievement in Natural Science between as students who were taught direct feedback were higher than students who were taught by delayed feedback. It could be observed from average scores in natural science as $\bar{X}_{\mathrm{A} 1}=16,86$ was higher that $\overline{\mathrm{X}}_{\mathrm{A} 2}=15,68,(2)$ there was difference in interaction between feedback and spatial cognitive style in natural science, (3) group of students who had high spatial cognitive, the learning achievement who were taught by direct feedback was higher than delayed feedback as it could be observed from average scores $\overline{\mathrm{X}}_{\mathrm{A} 1 \mathrm{~B} 1}=19,57$ was higher than $\overline{\mathrm{X}}_{\mathrm{A} 2 \mathrm{~B} 1}=15,93$ (4) group of students who had low spatial cognitive, the learning achievement who were taught by direct feedback was lower than delayed feedback as it could be observed from average score $\overline{\mathrm{X}}_{\mathrm{A} 1 \mathrm{~B} 2}=14,14$ was smaller than $\overline{\mathrm{X}}_{\mathrm{A} 2 \mathrm{~B} 2}=15,44$.
\end{abstract}

Keywords: Technique of Giving Feedback, Cognitive Style, Learning Achievement of Natural Science

\section{A. PENDAHULUAN}

Dalam upaya meningkatkan mutu pembelajaran, para praktisi dan pengembang teknologi pembelajaran telah banyak memperkenalkan dan menerapkan berbagai metode, pendekatan dan strategi yang disesuaikan dengan karakteristik peserta didik. Mutu 
pembelajaran dipengaruhi oleh kualitas proses pelaksanaan pembelajaran, juga terkait erat dengan karakteristik pembelajar atau peserta didik. Karakteristik peserta didik yang dimaksudkan adalah antara lain kecenderungan gaya belajar peserta didik yang unik dan khas, sebagai suatu variable kondisi pembelajaran yang harus diterima sebagaimana adanya, dan tidak dapat dimanipulasi oleh guru atau pengembang teknologi pembelajaran.

Kualitas suatu desain dan proses pembelajaran dapat diketahui dengan cara melakukan evaluasi. Pada saat evaluasi guru juga harus diberikan penguatan yang berupa pemberian balikan. Pemberian balikan merupakan salah satu teknik penyajian dalam pembelajaran, sebagai salah satu dari tahapan proses pembelajaran, yang berhubungan dengan upaya guru untuk memantau atau mengendalikan proses pencapaian hasil pembelajaran. Teknik penyajian pemberian balikan lebih umum dikenal dengan "umpan balik" atau "feedback". Disebut "teknik" karena pada tahapan pemberian balikan, guru dapat melakukan berbagai cara yang praktis dan mudah sebagai suatu cara yang dikembangkan untuk memudahkan dirinya memperoleh informasi secepat-cepatnya terhadap usahanya melakukan proses perbaikan pelaksanaan pembelajaran.

Pemberian balikan dianggap positif, manakala ditujukan untuk menggali informasi kemampuan peserta didik atau menyampaikan perbaikan/koreksi terhadap kesalahan atau kekurangan-kekurangan yang dilakukan oleh peserta didik. Salah satu prinsip paling mendasar dalam pemberian balikan adalah dimensi waktu. Dalam pemberian balikan dimensi waktu ikut berpengaruh dalam malaksanakan proses penilaian hasil belajar peserta didik. Musnandar (2006) mengemukakan bahwa balikan adalah salah satu teknik untuk membuat peserta didik aktif mempelajari kembali kegagalannya dalam mengerjakan tes atau latihan.

Konsep pembejalaran IPA yang cenderung abstrak dan kompleks, menuntut kemampuan abstraksi yang tinggi dari peserta didik dalam memahami pengetahuan atau konsep yang diperolehnya selama mengikuti proses pembelajaran. kemampuan abstrak terkait dengan tingkah laku kognitif peserta didik yang disebut gaya kognitif. Gaya kognitif merupakan sikap atau kecenderungan tingkah laku yang relatif stabil pada diri peserta didik dalam menerima, memahami, mengingat, berpikir dan menyelesaikan masalah.

Salah satu dimensi gaya kognitif adalah gaya kognitif spasial. Gaya kognitif spasial terkait dengan kemampuan melihat dan mengamati dunia visual spasial secara akurat, dan 
kemampuan bertindak atas persepsi tersebut. Gaya kognitif spasial dimaksud bila diperhatikan dalam pembelajaran diprediksi akan menentukan keefektifan strategi pengorganisasia pembelajaran. oleh karena itu, gaya kognitif ditempatkan sebagai salah satu variabel yang digunakan dalam penelitian ini.

\section{B. KAJIAN TEORETIS}

\section{Hakekat Hasil Belajar IPA}

Ilmu pengetahuan berkembang semakin luas, mendalam dan kompleks sejalan dengan perkembangan peradaban manusia. Meskipun demikian istilah penggunaan istilah natural science masih tetap digunakan sebagai Ilmu Pengetahuan Alam (IPA). Trianto (2011: 136-137) menyatakan pada hakikatnya IPA dibangun atas dasar produk ilmiah, proses ilmiah, dan sikap ilmiah. Pembelajaran IPA pada hakikatnya adalah ilmu untuk mencari tahu, memahami alam semesta secara sistematik dan mengembangkan pemahaman ilmu pengetahuan tentang gejala alam yang dituangkan berupa fakta, konsep, prinsip, dan hukum yang teruji kebenarannya.

Pengelolaan pembelajaran IPA di sekolah, guru harus dapat memberikan pengetahuan peserta didik mengenai konsep yang terkandung dalam materi IPA tersebut. Selain konsep, hendaknya guru dapat menanamkan sikap ilmiah melalui model-model pembelajaran yang dilakukannya. Untuk belajar IPA diperlukan cara khusus yang disebut dengan metode ilmiah. Metode ilmiah ini menekankan pada adanya masalah, adanya hipotesa, adanya analisa data untuk menjawab masalah atau membuktikan hipotesa, dan diakhiri dengan adanya kesimpulan atau generalisasi yang merupakan jawaban resmi dari masalah yang diajukan.

Winkel (1996:53) bahwa belajar sebagai suatu aktivitas mental/psikis yang berlangsung dalam interaksi aktif dengan lingkungan yang menghasilkan perubahanperubahan dalam pengetahuan, pemahaman, keterampilan dan nilai sikap. Menurut Skinner sebagaimana diungkapkan Uno (2012:20), belajar adalah hasil pasangan stimulus dan respon, kemudian diadakan penguatan (reinforcement) diperkuat akan cenderung diulang. Jufri (2013:9) mengungkapkan teori belajar adalah perubahan dalam tingkah laku sebagai akibat dari interaksi antara stimulus dan respon. Berdasarkan pengertian di atas dapat disimpulkan bahwa belajar adalah suatu proses yang membuat seseorang mengalami 
perubahan tingkah laku yang relatif menetap pada diri seseorang sebagai hasil dari suatu latihan dan pengalaman melalui proses kognitif peserta didik.

Poerwanto (1986: 28) mengungkapkan hasil belajar yaitu hasil yang dicapai oleh seseorang dalam usaha belajar sebagaimana dinyatakan dalam raport. Selanjutnya Winkel (1996: 162) mengatakan hasil belajar adalah suatu bukti keberhasilan belajar atau kemampuan seseorang peserta didik dalam melakukan kegiatan belajarnya sesuai dengan bobot yang dicapainya.

\section{Pemberian Balikan}

Rustiyah N.K (1991:23) mengemukakan tentang pengertian pemberian balikan, Pemberian balikan adalah informasi atau pemberitahuan guru kepada peserta didik baik secara lisan atau tertulis terhadap salah benarnya jawaban peserta didik dari hasil dalam mengerjakan tes atau latihan setelah selesai mengikuti program pembelajaran yang dirumuskan oleh guru dengan tujuan agar peserta didik terangsang atau termotivasi untuk berusaha merespon mencari pembetulan. Pendapat senada juga disampaikan oleh Daw dan Gage dalam Rustiyah N.K (1991:23), pemberian balikan adalah pemberian informasi kepada peserta didik sampai sejauh mana ia telah mencapai tujuan pembelajaran yang telah dirumuskan. Kim Ji Hyun (2013), memberi definisi pemberian balikan adalah suatu komunikasi antara guru dan peserta didik dalam hal memudahkan peserta didik memperbaiki kekurangannya dalam proses pembelajaran.

Kiram (1993:141), pemberian balikan merupakan pemberian koreksi terhadap unjuk kerja yang ditampilkan anak didik. Selanjutnya maksud pemberian balikan adalah bahwa pemberian balikan dapat mempercepat penguasaan suatu keterampilan dan tanpa pemberian balikan akan memperlambat proses pencapaian hasil yang optimal.

Pemberian balikan langsung maupun pemberian balikan tertunda memiliki perbedaan kondisi dalam pelaksanaan pemberian tindakan. Perbedaan kondisi tersebut dapat di lihat melalui gambar 1 tentang desain pemberian balikan langsung dan pemberian balikan tertunda.

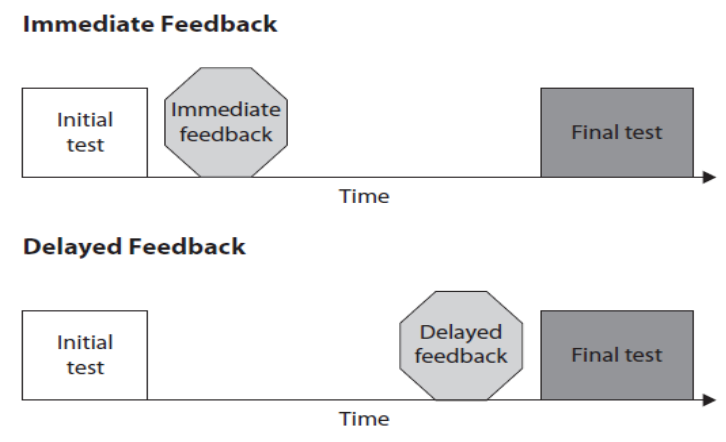


Gambar 1. Desain pemberian balikan langsung dan balikan tertunda (di adaptasi dari Metcalfe, Kornell and Finn,Memory \& Cognition 2009, 37 (8), 1077 1087doi:10.3758/MC.37.8.1077)

Sumber: http://www.researchgate.net

Dapat dilihat perbedaan waktu pelaksanaan pemberian balikan. Pada balikan langsung pemberian balikan dilaksanakan saat pembelajaran dengan waktu yang terbatas. Waktu antara proses pembelajaran dengan tes akhir memiliki waktu yang lama. Sedangkan pemberian balikan tertunda memiliki waktu yang lama untuk mengerjakan latihan soal yang diberikan.Waktu antara proses pembelajaran dengan tes akhir memiliki waktu yang singkat.

Ada dua kondisi: pemberian balikan langsung dan pemberian balikan tertunda. Percobaan selama lima sesi yang dimulai dari pra tes dan post tes dilaksanakan pada pertemuan kelima. Gambaran dan desain pelaksanaan ekperimen ditunjukan pada gambar 2 berikut ini.

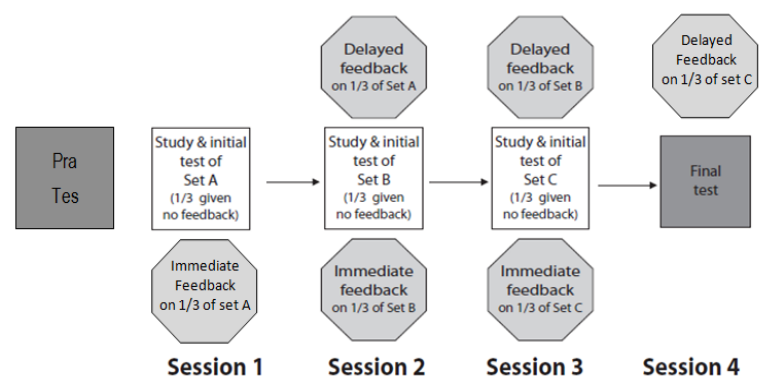

Gambar 2. Desain pelaksanaan ekperimen (di adaptasi dari Metcalfe, Kornell and Finn, Memory \& Cognition 2009, 37 (8), 1077-1087doi:10.3758/MC.37.8.1077)

Sumber: http://www.researchgate.net

Prosedur pelaksanaan pemberian balikan sebagaimana diungkapkan oleh Kim Ji Hyun (2013:116), terdiri dari 4 tahapyaitu: (1) Tahap Komposisi/penyampaian materi (pemberian balikan), (2) refleksi dan (3) tahap revisi dan (4) penulisan ulang.

Dari tahap ini kemudian dikembangkan ke prosedur tahapan pelaksanaan pemberian balikan langsung dalam proses pembelajaran yang terdiri: (1) pelaksanaan tes awal, (2) penyampaian materi pembelajaran, (3) mulai mengerjakan latihan soal yang diberikan oleh guru, (4) guru memberikan koreksi terhadap jawaban peserta didik, (5) 
memberikan penguatan, (6) menyimpulkan materi pembelajaran (7) menyampaikan materi pada pertemuan berikutnya dan menutup pembelajaran.

\section{Gaya Kognitif Spasial}

Menurut Keefe (1987:7), gaya kognitif merupakan bagian dari gaya belajar yang mengambarkan kebiasaan berprilaku yang tetap dalam diri seseorang dalam menerima, memikirkan, memecahkan masalah maupun menyimpan informasi. Gaya kognitif dideskripsikan sebagai cara bagaimana seseorang mengolah informasi. Sedangkan menurut Ausburn (Uno, 2012 :186) gaya kognitif mengacu pada proses kognitif seseorang yang berhubungan dengan pemahaman, pengetahuan, persepsi, pikiran, imajinasi dan pemecahan masalah.

Witkin (Uno, 2012 : 186).mengemukakan bahwa gaya kognitif sebagai ciri khas peserta didik dalam belajar Sedangkan Messich, mengemukakan bahwa gaya kognitif merupakan kebiasaan seseorang dalam memproses informasi. Sementara Keefe mengemukakan bahwa gaya kognitif merupakan bagian dari gaya belajar yang mengambarkan kebiasaan berprilaku yang relatif tetap dalam diri seseorang dalam menerima, memikirkan, memecahkan masalah maupun dalam menyimpan informasi (Uno, 2012 : 186).

Gaya kognitif menunjukan adanya variasi antar individu dalam pendekatannya terhadap suatu tugas, tetapi variasi ini tidak menunjukan tingkat intelegensi atau kemampuan tertentu. Karakteristik individu yang memiliki gaya kognitif yang sama belum tentu memiliki kemampuan yang sama. Apalagi individu yang memiliki gaya kognitif yang berdeba, kecenderungan perbedaan kemampuan yang dimilikinya lebih besar.

Menurut Keefe (Uno, 2012 : 187) mengemukakan bahwa gaya kognitif dipilah dalam dua kelompok, yaitu gaya dalam menerima informasi (reception Style) dan gaya dalam pembentukan konsep dan retensi (concept formation and retention style). Keefe (Uno, 2012 : 187) juga menambahkan, bahwa gaya kognitif merupakan bagian dari gaya belajar, dan gaya belajar berhubungan (namun berbeda) dengan kemampuan intelegtual. Terdapat perbedaan antara kemampuan (abilitiy) dan gaya (style). Kemampuan mengacu pada isi kognisi yang menyatakan macam informasi apa yang telah diproses, dengan langkah bagaimana, dan dalam bentuk apa. Sedangkan gaya lebih mengacu pada proses kognitif yang menyatakan bagaimana isi informasi tersebut diproses. 
Kedudukan gaya kognitif dalam proses pembelajaran tidak dapat diabaikan. Hal ini sesuai dengan pandangan Reigeluth (1984) bahwa dalam variabel pengajaran, gaya kognitif merupakan salah satu karakteristik peserta didik yang masuk dalam variabel kondisi pembelajaran, di samping karakteristik peserta didik lainnya seperti motivasi, sikap, bakat, minat kemampuan berpikir dan lain-lain. Sebagai salah satu karakteristik, kedudukan gaya kognitif dalam proses pembelajaran penting diperhatikan guru atau perancang pembelajaran sebab rancangan pembelajaran yang disusun dengan mempertimbangkan gaya kognitif berarti menyajikan materi pembelajaran yang sesuai dengan karakteristik dan potensi yang dimiliki peserta didik.

Gaya kognitif yang dilibatkan adalah gaya kognitif spasial tinggi (GKST) dan gaya kognitif spasial rendah (GKSR). Gaya kognitif baik GKST dan GKSR ini dapat digunakan untuk melihat seberapa kecepatan dalam merespons informasi ini tidak untuk menentukan baik atau buruk, tetapi menekankan kekuatan atau kelemahan yang nantinya akan menjadi hal yang perlu dipertimbangkan guru dalam merancang strategi pembelajaran. Perbedaan karakteristik kedua gaya kognitif GKST dan GKSR tersebut tentunya menyebabkan perbedaan penerimaan informasi dalam proses pembelajaran. Dengan demikian, akibat perbedaan gaya kognitif serta perbedaan strategi pembelajaran diduga berpengaruh pada hasil belajar. Perbedaan kedua dimensi gaya kognitif dapat di lihat pada table 1 berikut ini:

Tabel 1. Karakteristik Dimensi Gaya Kognitif Spasial.

\begin{tabular}{|c|c|c|}
\hline $\begin{array}{c}\text { Dimensi Gaya } \\
\text { Kognitif Spasial } \\
\text { Tinggi (GKST) }\end{array}$ & $\begin{array}{c}\text { Karakteristik } \\
\text { Gaya Kognitif Spasial }\end{array}$ & $\begin{array}{c}\text { Dimensi Gaya } \\
\text { Kognitif Spasial } \\
\text { Rendah (GKSR) }\end{array}$ \\
\hline Tinggi & - Berpikir Imajinatif & Rendah \\
\hline Tinggi & - Kecepatan berpikir hal-hal yang abstrak & Rendah \\
\hline Tinggi & $-\begin{array}{l}\text { Memecahkan informasi disertai dengan } \\
\text { citra mental }\end{array}$ & Rendah \\
\hline Tinggi & - Menganalisis obyek visual & Rendah \\
\hline Rendah & - Kemampuan berbicara & Tinggi \\
\hline Tinggi & - Bertindak mempertimbangkan risiko \\
\hline Tinggi & - Kecepatan memecahkan masalah & Rendah \\
\hline Rendah & - Ketergantungan kepada orang lain & Tinggi \\
\hline Tinggi & - Keikutsertaan rotasi mental dalam & Rendah \\
\hline Tinggi & - Kemampuan mencipta sesuatu & Rendah \\
\hline
\end{tabular}


SEMINAR NASIONAL PENDIDIKAN KIMIA BERBASIS KEARIFAN LOKAL

\begin{tabular}{|c|c|c|}
\hline Tinggi & - Menciptakan sesuatu seni & Rendah \\
\hline Tinggi & - Merekayasa bangunan & Rendah \\
\hline Tinggi & - Gubahan music & Rendah \\
\hline
\end{tabular}

Sumber: (Uno, $2012: 193)$

\section{METODOLOGI PENELITIAN}

\section{Tempat dan Waktu Penelitian}

Penelitian ini dilaksanakan di SMP Negeri 2 Bongomeme salah satu sekolah menengah pertama yang terletak di Desa Duwanga Kecamatan Dungaliyo Kabupaten Gorontalo.

\section{Jenis dan Disain Penelitian}

Penelitian ini mengunakan metode eksperimen desain faktorial ANAVA 2x2. Variabel yang diteliti adalah teknik pemberian balikan sebagai variabel kondisi terhadap gaya kognitif. Teknik pemberian balikan (A) terdiri dari teknik pemberian balikan langsung $\left(\mathrm{A}_{1}\right)$ dan teknik pemberian balikan tertunda $\left(\mathrm{A}_{2}\right)$, sedangkan gaya kognitif spasial tinggi $\left(\mathrm{B}_{1}\right)$ dan gaya kognitif spasial rendah $\left(\mathrm{B}_{2}\right)$.

\section{Cara Pengumpulan Data}

Data yang dikumpulkan dalam penelitian adalah data tentang gaya kognitif dan data hasil belajar peserta didik. Pengumpulan data dilakukan dengan menggunakan dua macam instrumen meliputi (a) Instrumen untuk mengukur variabel atribut yaitu tes gaya kognitif, dan (b) instrumen untuk mengukur variabel terikat yaitu tes hasil belajar peserta didik.

Instrumen gaya kognitif menggunakan instrumen gaya kognitif yang baku (diadaptasi dari disertasi Hamzah B. Uno (2004) yang sudah divaliditasi dan direliabilitas). Sedangkan tes hasil belajar disusun berdasarkan materi yang dibelajarkan pada materi tekanan sesuai dengan silabus IPA kelas VIII.

Pengukuran gaya kognitif dilakukan pada pertemuan pertama pelaksanaan penelitian. Pengukuran gaya kognitif diukur dengan menggunakan bagian instrumen gaya kognitif. Dengan menggunakan tes ini dapat ditentukan tinggi rendahnya gaya kognitif spasial peserta didik.

\section{Teknik Analisis Data}

Analisis yang digunakan meliputi analisis deskriptif dan analisis infrensial. Analisis deskriptif dilakukan untuk menyajikan data setiap variabel dalam besaran-besaran statistik seperti rata-rata (mean), nilai tengah (median), frekuwensi terbanyak (modus), simpangan 
baku (standar deviasi), dan menvisualisasikan ke dalam bentuk tabel distribusi frekuwensi dan histogram, sedangkan analisis infrensialmerupakan uji persyaratan analitis dan uji hipotesis berupa: (1) uji normalitas data, uji Liliefors (Sudjana, 2005:466), uji homogenitas varians, dengan uji Barlett (Sudjana, 2005: 261) dan uji Analisis of Varians (ANAVA) dua jalur untuk menguji hipotesis penelitian yang dilakukan dengan uji tuckey.

Dengan menggunakan harga rata-rata (mean) ditambah standar deviasi merupakan batas kelompok peserta didik yang mempunyai gaya kognitif spasial tinggi, dan harga ratarata (mean) dikurangi standar deviasi sebagai kelompok peserta didik yang mempunyai gaya kognitif spasial rendah. Adapun kelompok subyek yang mempunyai gaya kognitif spasial tinggi dan gaya kognitif spasial tinggi. Untuk menguji validas butir tes terbentuk data diskrit atau dikotomi yaitu benar diberi skor 1 dan salah diberi skor 0 menggunakan formula korelasi poin biserial yaitu korelasi antar skor butir tes dengan skor total tes, dan untuk menguji reliabilitas instrument menggunakan rumus Alpha Cronbach.

\section{HASIL PENELITIAN DAN PEMBAHASAN}

Data hasil belajar peserta didik pada mata pelajaran IPA di kelas VIII SMP Negeri 2 Bongomeme disajikan dalam delapan kelompok, (1) data hasil belajar IPA peserta didik yang dibelajarkan dengan teknik pemberian balikan langsung (Sel $\left.\mathrm{A}_{1}\right)$; (2) data hasil belajar IPA peserta didik yang dibelajarkan dengan teknik pemberian balikan tertunda (Sel $\left.\mathrm{A}_{2}\right)$; (3) data hasil belajar IPA peserta didik yang memiliki gaya kognitif spasial tinggi (Sel $\left.\mathrm{B}_{1}\right)$; (4) data hasil belajar IPA peserta didik yang memiliki gaya kognitif spasial rendah(Sel $\left.B_{2}\right)$; (5) data hasil belajar IPA peserta didik yang memiliki gaya kognitif spasial tinggi yang dibelajarkan dengan teknik pemberian balikan langsung (Sel $\left.\mathrm{A}_{1} \mathrm{~B}_{1}\right)$; (6) data hasil belajar IPA peserta didik yang memiliki gaya kognitif spasial rendah yang dibelajarkan dengan teknik pemberian balikan langsung $\left(\mathrm{Sel} \mathrm{A}_{1} \mathrm{~B}_{2}\right)$; (7) data hasil belajar IPA peserta didik yang memiliki gaya kognitif spasial tinggi yang dibelajarkan dengan teknik pemberian balikan tertunda (Sel $\left.\mathrm{A}_{2} \mathrm{~B}_{1}\right)$; (8) data hasil belajar IPA peserta didik yang memiliki gaya kognitif spasial rendah yang dibelajarkan dengan teknik pemberian balikan tertunda $\left(\operatorname{Sel} \mathrm{A}_{2} \mathrm{~B}_{2}\right)$.

Hasil perhitungan dengan Uji Liliefors menunjukan bahwa kedelapan kelompok data tersebut memiliki tingkat normalitas data disajikan dalam tabel 2 berikut ini :

Tabel 2. Hasil Uji Normalitas Data Hasil Belajar IPA pada masing-masing kelompok 


\begin{tabular}{|c|c|c|c|c|}
\hline Kelompok & $\mathrm{N}$ & $\mathrm{L}_{0}$ & $\mathrm{~L}_{\mathrm{t}(\alpha=0,01)}$ & Kesimpulan \\
\hline $\mathrm{A}_{1}$ & 28 & 0,1374 & 0,187 & Normal \\
\hline $\mathrm{A}_{2}$ & 28 & 0,1586 & 0,187 & Normal \\
\hline $\mathrm{B}_{1}$ & 28 & 0,1026 & 0,187 & Normal \\
\hline $\mathrm{B}_{2}$ & 28 & 0,1483 & 0,187 & Normal \\
\hline $\mathrm{A}_{1} \mathrm{~B}_{1}$ & 14 & 0,1230 & 0,261 & Normal \\
\hline $\mathrm{A}_{1} \mathrm{~B}_{2}$ & 14 & 0,1271 & 0,261 & Normal \\
\hline $\mathrm{A}_{2} \mathrm{~B}_{1}$ & 14 & 0,1566 & 0,261 & Normal \\
\hline $\mathrm{A}_{2} \mathrm{~B}_{2}$ & 14 & 0,1909 & 0,261 & Normal \\
\hline
\end{tabular}

Dari tabel di atas dapat diahami bahwa $\mathrm{L}_{0}$ kedelapan Kelompok tersebut lebih kecil dari $\mathrm{L}_{\mathrm{t}}\left(\mathrm{L}_{0}<\mathrm{L}_{\mathrm{t}}\right)$, ini berarti $\mathrm{H}_{0}$ diterima. Dengan demikian dapat disimpulkan bahwa sampel dari kedelapan kelompok di atas adalah berasal dari populasi yang berdistribusi normal.

Pengujian hipotesis ini dilakukan dengan teknik Analisis Varians 2 jalur (ANAVA 2 x 2), kemudian dilakukan uji lanjut dengan menggunakan uji tuckey. Analisis Varians dua jalur adalah suatu teknik perhitungan (statistik parametrik) yang bertujuan untuk menyelidiki dua pengaruh, yaitu pengaruh utama (main effect) dan pengaruh interaksi (interaction effect).

Adapun hasil perhitungan ANAVA 2 jalur ini secara ringkas dapat di lihat pada tabel 3 berikut ini.

Tabel 3. Rangkuman Hasil Perhitungan ANAVA Data Hasil Belajar IPA

\begin{tabular}{|c|c|c|c|c|c|c|}
\hline Sumber Variansi & $\begin{array}{c}\text { Jumlah } \\
\text { Kuadrat } \\
(\mathbf{J K})\end{array}$ & $\mathbf{d k}$ & $\begin{array}{c}\text { Rata-rata } \\
\text { Kuadrat } \\
(\mathbf{R K})\end{array}$ & $\mathbf{F}_{\text {hitung }}$ & $\begin{array}{c}\mathbf{F}_{\text {tabel }} \\
(\alpha=0,05)\end{array}$ & $\begin{array}{c}\mathbf{F}_{\text {tabel }} \\
(\alpha=0,01)\end{array}$ \\
\hline Antar Kolom & 19,45 & 1 & 19,45 & $4,09^{*}$ & 4,03 & 7,17 \\
\hline Antar Baris & 123,02 & 1 & 123,02 & $25,85^{* *}$ & 4,03 & 7,17 \\
\hline $\begin{array}{c}\text { Interaksi Kolom } \\
\text { \& Baris }\end{array}$ & 85,02 & 1 & 85,02 & $17,86^{* *}$ & 4,03 & 7,17 \\
\hline $\begin{array}{c}\text { Kekeliruan dalam } \\
\text { Kelompok (d) }\end{array}$ & 247,50 & 52 & 4,76 & - & - & - \\
\hline T o t a l & 474,98 & 55 & 232,24 & - & - & - \\
\hline
\end{tabular}

Keterangan : * = signifikan pada $\alpha=0,05$

$* *$ = sangat signifikan pada $\alpha=0,01$

Berdasarkan rangkuman perhitungan ANAVA di atas, dapat dijelaskan:

1. Hasil analisis varians dua jalur antar kolom diperoleh harga $F_{\text {hitung }}=4,09$ lebih besar dari $\mathrm{F}_{\text {tabel }}=4,03$ pada taraf signifikansi $\alpha=0,05$. Hasil perhitungan menunjukan skor rata-rata hasil belajar IPA pada peserta yang dibelajarkan dengan teknik pemberian balikan langsung $\left(\mathrm{A}_{1}\right)$ sebesar 16,86 lebih tinggi dari skor rata hasil belajar IPA pada 
peserta didik yang dibelajarkan dengan teknik pemberian balikan tertunda $\left(\mathrm{A}_{2}\right)$ sebesar 15,68 dengan demikian hipotesis pertama yang menyatakan, secara keseluruhan hasil belajar IPA pada peserta didik yang dibelajarkan dengan teknik pemberian balikan langsung lebih tinggi dari hasil belajar IPA pada peserta didik yang dibelajarkan dengan teknik pemberian balikan tertunda.

2. Hasil analisis varians dua jalur antara kolom dan baris diperoleh harga $F_{\text {hitung }}=17,86$ lebih besar dari $F_{\text {tabel }}=7,17$ pada taraf signifikansi $\alpha=0,01$. Dengan demikian hipotesis alternatif yang menyatakan terdapat interaksi antara teknik pemberian balikan dan gaya kognitif terhadap hasil belajar IPA diterima secara signifikan.

Hasil perhitungan uji lanjut dengan uji tuckey untuk kedua kelompok/subyek yang dibandingkan tersebut disajikan pada tabel berikut.

Tabel 4. Ringkasan Hasil perhitungan Uji Tuckey $(\alpha=0,05)$

\begin{tabular}{|c|c|c|c|c|c|}
\hline No & $\begin{array}{c}\text { Kelompok } \\
\text { Perbandingan }\end{array}$ & Qhitung & Qtabel (0,05) & Qtabel (0,01) & Kesimpulan \\
\hline 1. & $\mathrm{~A}_{1} \mathrm{~B}_{1}$ dengan $\mathrm{A}_{2} \mathrm{~B}_{1}$ & 6,25 & 3,03 & 4,21 & Signifikan \\
\hline 2. & $\mathrm{~A}_{1} \mathrm{~B}_{2}$ dengan $\mathrm{A}_{2} \mathrm{~B}_{2}$ & 3,12 & 3,03 & 4,21 & Signifikan \\
\hline
\end{tabular}

Dari hasil perhitungan uji tuckey di atas, maka dapat ditarik kesimpulan sebagai berikut:

1. Hasil analisis dengan uji tuckey untuk kelompok siswa $\left(\mathrm{A}_{1} \mathrm{~B}_{1}\right)$ yang memiliki gaya kognitif spasial tinggi menunjukan, bahwa teknik pemberian balikan langsung memberikan pengaruh yang lebih baik terhadap hasil belajar IPA dibandingkan dengan teknik pemberian balikan tertunda. Harga $Q_{\text {hitung }}=6,25>Q_{\text {tabel }}=3,03-(\alpha=0,05)$. Juga nilai rata-rata hasil belajar dari kelompok $\mathrm{A}_{1} \overline{\mathrm{B}}_{1}(X=19,57)$ lebih tinggi dari kelompok $\mathrm{A}_{2} \mathrm{~B}_{1}(X=15,93)$. Artinya, hipotesis ini diterima atau teruji secara signifikan.

2. Hasil analisis dari uji tuckey untuk kelompok siswa $\left(\mathrm{A}_{2} \mathrm{~B}_{2}\right)$ yang memiliki gaya kognitif spasial rendah menunjuka, bahwa teknik pemberian balikan tertunda memberikan pengaruh yang lebih baik terhadap hasil belajar IPA dibandingkan dengan teknik pemberian balikan langsung $\left(\mathrm{A}_{1} \mathrm{~B}_{2}\right)$. Harga $\mathrm{Q}_{\text {hitung }}=3,12>\mathrm{Q}_{\text {tabel }}=3,03(\alpha=0,05)$. Juga nilai rata-rata hasil belajar dari kelompok $\mathrm{A}_{2} \mathrm{~B}_{2}(X=14,14)$ lebih tinggi dari kelompok $\mathrm{A}_{1} \mathrm{~B}_{2}(X=15,88)$. Artinya, hipotesis ini diterima atau diterima secara signifikan.

\section{PEMBAHASAN}


1. Hasil belajar peserta didik yang dibelajarkan dengan teknik pemberian balikan langsung lebih tinggi dari pada hasil belajar peserta didik yang dibelajarkan dengan teknik pemberian balikan tertunda.

Berdasarkan hasil analisis data, perbedaan hasil belajar IPA yang dibelajarkan dengan teknik pemberian balikan langsung dan teknik pemberian balikan tertunda. hal ini menunjukan koefisien ANAVA (F) sebesar 4,09 yang ternyata signifikan.

Teknik pemberian balikan langsung menunjukan penerimaan informasi kepada peserta didik sebagai penerima pasif informasi menjadi pengkonstruksi aktif dalam proses pembelajaran. Pengerjaan latihan yang dilaksanakan oleh peserta didik langsung dipantu oleh guru sehingga guru dapat memberikan balikan secara langsung apabila terdapat kekeliruan peserta didik dalam menyelesaikan permasalahan. Pemberian balikan tertunda berupa pemberian tugas yang dikerjakan diluar jam pembelajaran. pemberian balikan tertunda memiliki tujuan agar peserta didik memperoleh hasil belajar yang lebih baik, karena siswa dapat melaksanakan latihan selama melakukan tugas. pemberian balikan tertunda dilaksanakan dengan memberikan balikan kepada peserta didik untuk dikerjakan di rumah dengan mempertanggung jawabkan hasil pekerjaannya kepada guru.

Teknik pemberian balikan ini dimaksudkan untuk memberikan evaluasi terhadap mata pelajaran yang telah dipelajari serta memberikan informasi berupa koreksi terhadap unjuk kerja yang ditampilkan peserta didik. Suatu aktivitas belajar dengan pemberian balikan langsung akan meningkatkan ingatan jangka pendek menuju ingatan yang lebih tetap (permanen). Sebagaimana diungkapkan oleh Metcalfe, Kornell and Finn (2009: 1078) mengatakan bahwa pengolahan kesulitan pembelajaran bisa diselesaikan dengan pemberian balikan langsung yang dapat meningkatkan memori, sehingga pemberian balikan langsung lebih baik daripada pengolahan memori dengan menggunakan pemberian balikan tertunda

\section{Ada pengaruh interaksi antara teknik pemberian balikan dan gaya kognitif terhadap hasil belajar IPA}

Hasil uji hipotesis ini menunjukan adanya pengaruh interaksi antara teknik pemberian balikan dengan gaya kognitif peserta didik dalam mempengaruhi hasil belajar IPA menjadi konsepsi ilmiah. Hal ini ditegaskan dalam pengujian hipotesis dengan $F_{\text {hitung }}$ 17,86 sedangkan $F_{\text {tabel }}$ pada $\alpha=0,01$ yang sebesar 7,17. Dengan demikian kriteria yang ada 
berarti terdapat pengaruh interaksi antara teknik pemberian balikan dan gaya kognitif terhadap hasil belajar IPA.

Peserta didik dengan gaya kognitif spasial tinggi cenderung dapat menganalisis dan memahami terhadap informasi yang dipelajari dengan baik apabila proses penyelesain latihan soal diberikan dengan pemberian balikan langsung. Peserta didik yang memiliki gaya kognitif spasial tinggi lebih tepat menggunakan pembelajaran dengan pemberian balikan langsung. Peserta didik dengan gaya kognitif spasial rendah cenderung dapat menganalisis dan memahami terhadap informasi yang dipelajari dengan baik apabila proses penyelesain latihan soal diberikan dengan pemberian balikan tertunda. Disamping itu, mereka dapat mengembangkan struktur materi pembelajaran yang disajikan dan mampu memecahkan masalah dengan bimbingan. Peserta didik yang memiliki gaya kognitif spasial rendah lebih tepat menggunakan pembelajaran dengan pemberian balikan tertunda.

3. Pada kelompok peserta didik yang memiliki gaya kognitif spasial tinggi, hasil belajar IPA peserta didik yang dibelajarkan dengan teknik pemberian balikan langsung lebih tinggi daripada peserta didik yang dibelajarkan dengan teknik pemberian balikan tertunda

Hasil belajar IPA yang memiliki gaya kognitif spasial tinggi dengan dibelajarkan dengan teknik pemberian balikan langsung memiliki skor rata-rata 19,57 lebih tinggi dari pada hasil belajara IPA pada peserta didik yang dibelajarkan dengan teknik pemberian balika tertunda dengan skor rata-rata 15,93 dalam perhitungan lanjutan dengan Uji tuckey

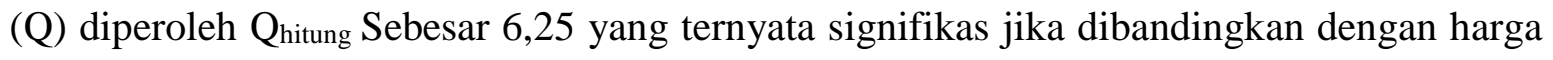
Qtabel yang sebesar 3,03

Peserta didik yang dibelajarkan dengan teknik peberian balikan langsung hasil belajarnya lebih tinggi daripada peserta didik yang dibelajarkan dengan teknik pemberian tertunda hal ini disebabkan karena peserta didik yang menyelesaian latihan soal secara langsung diberikan masukan atau penguatan informasi oleh guru tentang pengerjaan soal yang dikerjakan sesuai dengan jawaban yang diharapkan serta bimbingan terhadap langkahlangkah pengerjaan soal latihan yang dikerjakan dengan waktu yang singkat.

Peserta didik yang memiliki gaya kognitif spasial tinggi proses pembelajaran dengan menggunakan teknik pemberian balikan langsung sangat tepat dibandingkan proses pembelajaran dengan teknik pemberian balikan tertunda untuk diterapkan pada peserta 
didik yang memiliki gaya kognitif spasial tinggi. Hasil penelitian ini dapat diasumsikan bahwa peserta didik dengan gaya kognitif spasial tinggi mampu memahami dan menguasai materi dari latihan yang dilaksanakan. Dengan kata lain gaya kognitif spasial tinggi dan diajarkan dengan teknik pemberian balikan langsung dapat memudahkan peserta didik dalam menguasai, memahami, menganalisis, keterampilan.

4. Pada kelompok peserta didik yang memiliki gaya kognitif spasial rendah, hasil belajar IPA peserta didik yang dibelajarkan dengan teknik pemberian balikan langsung lebih rendah daripada peserta didik yang dibelajarkan dengan teknik pemberian balikan tertunda

Dari hasil analisis data, diduga bahwa terdapat perbedaan hasil belajar IPA yang memiliki gaya kognitif spasial rendah dengan mengikuti pembelajaran dengan teknik pemberian balikan langsung dan teknik pemberian balikan tertunda. hasil yang menunjukan angka pada uji tuckey (Q) sebesar 3,12 jika dibandingkan dengan harga $\mathrm{Q}_{\text {tabel }}$ yang sebesar 3,03 yang ternyata signifikan. Dari hasil uji tuckey ini menunuukan hasil belajar IPA yang memiliki gaya kognitif spasial rendah dengan teknik pemberian balikan tertunda memiliki skor rata-rata 15,43 ternyata lebih tinggi dari teknik pemberian balikan langsung yang memiliki skor rata-rata 14,14

Teknik pemberian balikan tertunda berpengaruh positif terhadap hasil belajar IPA untuk peserta didik yang memiliki gaya kognitif spasial rendah. Peserta didik yang dibelajarkan pemberian balikan tertunda lebih unggul daripada peserta didik yang dibelajarkan pemberian balikan langsung. Hal ini disebabkan karena pembelajaran dengan pemberian balikan tertunda ini memberikan keuntungan kepada peserta didik untuk berfikir tentang kesalahan dan bagaimana memperbaiki kesalahan tersebut akan tetapi pemberian balikan tertunda ini jangan diberikan selang waktu terlalu lama diberikan dengan apabila lama maka peserta didik lupa terhadap kesalahan.

Hasil belajar IPA yang memiliki gaya kognitif spasial rendah ini dapat dipengaruhi dengan teknik pemberian balikan tertunda karena peserta didik membutuhkan waktu yang lebih lama untuk menganalisis, keterampilan mengenal dan memecahkan masalah, keterampilan menyimpulkan, menguasai dan menyelesaikan latihan yang diberikan oleh guru. Penyelesaian dan bimbingan yang lebih lama akan memberikan hasil yang positif untuk meningkatkan hasil belajar IPA. Sehingga dikatakan peserta didik yang memiliki 
gaya kognitif spasial rendah dibelajarkan dengan teknik pemberian balikan tertunda akan memberikan hasil yang lebih efektif dari pada peserta didik yang dibelajarkan dengan teknik pemberian balikan langsung

\section{E. SIMPULAN DAN SARAN}

\section{Simpulan}

Berdasarkan temuan dan pembahasan hasil penelitian, maka dapat disimpulkan halhal sebagai berikut:

1. Secara keseluruhan hasil belajar IPA pada peserta didik yang dibelajarkan dengan teknik pemberian balikan langsung lebih tinggidarihasil belajar IPA pada peserta didik yang dibelajarkan denganteknik pemberian balikan tertunda.

2. Terdapat pengaruh interaksi antara teknik pemberian balikan dan gaya kognitif peserta didik terhadap hasil belajar IPA.

3. Pada kelompok peserta didik yang memiliki gaya kognitif spasial tinggi, hasil belajar IPA pada peserta didik yang dibelajarkan dengan teknik pemberian balikan langsung lebih tinggi daripada peserta didik yang dibelajarkan dengan teknik pemberian balikan tertunda.

4. Pada kelompok peserta didik yang memiliki gaya kognitif spasial rendah, hasil belajar IPA pada peserta didik yang dibelajarkan dengan teknik pemberian balikan langsung lebih rendah daripada peserta didik yang dibelajarkan dengan teknik pemberian balikan tertunda.

\section{Saran}

Berdasarkan kesimpulan dan implikasi yang dikemukakan diatas, peneliti menyarankan beberapa hal sebagai berikut:

Pertama, sebagai pekerja profesional guru perlu merancang, mengembangkan, mengelola proses pembelajaran yang bervariatif yang disesuaikan dengan karakteristik peserta didik dan meteri pelajaran yang disajikan agar dapat menjangkau proses pembelajaran yang diterapkan yaitu teknik pemberian balikan langsung dan teknik pemberian balikan tertunda.

Kedua, guru perlu mengelompokkan peserta didik sesuai dengan gaya kognitif, merancang, mengembangkan dan mengelola pembelajaran sesuai karakteristik peserta didik tersebut.

Ketiga, guru perlu mengembangkan model pembelajaran dan memperhatikan teknik pemberian sehingga peserta didik dapat termotivasi dalam mengikuti pembelajaran, sebab 
peserta didik yang memiliki motivasi belajar yang tinggi cenderung menunjukan hasil belajar yang maksimal.

Keempat, bagi peneliti yang ingin melakukan penelitian tentang teknik pemberian balikan dan gaya kognitif peserta didik, disarankan untuk menganalisis gaya kognitif dengan baik agar dapat diketahui bahwa gaya kognitif berpengaruh terhadap hasil belajar peserta didik pada mata pelajaran IPA.

\section{F. DAFTAR PUSTAKA}

Dimyati dan Mudjiono.2005. Belajar dan Pembelajaran. Jakarta: Rineka Cipta

Hamalik. Herman. 2000, Metodologi Pembelajaran Ilmu Pendidikan Berdasarkan Kompetensi; Bandung: Mandar maju.

Hamalik Oemar. 2003. Proses Belajar Mengajar. Jakarta : PT. Bumu Aksara.

Jufri H.A Wahab. 2013, Belajar dan Pembelajaran SAINS. Bandung : Reka Cipta.

Keefe, Jame W. 1987. Learning Style Theory And Practice. Virginia. Reston, Va: National Association of Secondery School Principals (NASSP)

KiramYanuar. 1993. BelajarMotorik. Jakarta :Depdikbud.

Kim Ji Hyun. 2013. Learner Understanding of Written Corrective Feedback and Its Relationship with Immediate Uptake and Retention in EFL Classrooms. Keimyung University

Metcalfe Janet,dkk.2009. Delayed versus immediate feedback in children's and adults' vocabulary learning. Columbia University, New York, New York.

Musnandar. 2006. Keefektifan Pengajaran Melalui Pengaruh Interaktif Antara Pemberian Balikan Dan Motivasi Berprestasi Terhadap Perolehan Belajar.

Purwanto M. Ngalim. 1986. Evaluasi Hasil Belajar. Yogyakarta : Pustaka Pelajar

Reigeluth, C.M. 1984. The Evolution of Instructional Science; Toward a common Knowledge base. Education Technology.

Rofiq Zainur. 2005. Pengaruh Strategi Pembelajaran Dan Gaya Kognitif Terhadap Hasil Belajar Membaca Gambar Teknik Mesin. UNJ : Jakarta

Rustiyah, N.K. 1991. Strategi Belajar Mengajar. Jakarta: Bina Aksara.

Sudjana. 2005. Metode statistik. Bandung: Tarsito

Sudjana Nana. 1998. Penilaian Hasil Proses Belajar Mengajar. Bandung : Sinar Baru.

Trianto. 2010. Model Pembelajaran Terpadu. Jakarta : Bumi Aksara. 
Uno B. Hamzah. 2012. Orientasi Baru Dalam Psikologi Pembelajaran. Jakarta : Bumi Aksara.

2014. Variabel Penelitian dalam Pendidikan dan Pembelajaran. Jakarta : PT Ina Publikatama

Winkel, WS. 1996. Psikologi Pengajaran. Jakarta : Bumi Aksara

Wittkin, A.H. 1997. Field Dependent dan Field Independent cognitive style and their education iImplication Review of Education Research.Winter. New York : International Universitas Press 